\title{
Re-epithelization and density of collagen fibers on wound healing of mice's skin (Mus musculus) that treated with combination of chitosan membrane and eel (Monopterus albus) mucous
}

\author{
Deaoxi Renaschantika Djatumurti ${ }^{1}$, Afifatur Rafida ${ }^{1}$, Asha Yonika Putri Manalu ${ }^{2}$, and Tri \\ Wahyu Pangestiningsih ${ }^{3 *}$ \\ ${ }^{1}$ Undergraduate student, Faculty of Veterinary Medicine, Universitas Gadjah Mada, Jl. Fauna, No. 2, \\ Karangmalang, Catur Tunggal, Depok, Sleman, Daerah Istimewa Yogyakarta, Indonesia. 55281 \\ ${ }^{2}$ Undergraduate student, Faculty of Medicine, Public Health and Nursing, Universitas Gadjah Mada, \\ Jl. Farmako Sekip Utara, Sleman, Daerah Istimewa Yogyakarta, Indonesia. 55281 \\ ${ }^{3}$ Anatomy Department, Faculty of Veterinary Medicine, Universitas Gadjah Mada, Jl. Fauna, No. 2, \\ Karangmalang, Catur Tunggal, Depok, Sleman, Daerah Istimewa Yogyakarta, Indonesia. 55281
}

\begin{abstract}
Untreated skin wound can inhibit the wound healing process. Chitosan and eel mucous have biodegradable, biocompatible, and antimicrobial properties. This study aimed to determined the potential of combination between chitosan membrane and eel mucous extract in skin wound re-epithelization and collagen fibers deposition. Thirty adult male mice were divided into 5 groups, 6 animals/group. Skin wound were perform by punch biopsy in $0.5 \mathrm{~cm}$ diameter. Group I-IV respectively recieved: $10 \%$ povidone iodine; eel mucus extract and gauze; combination of $1 \%$ chitosan membrane and eel mucus; $1 \%$ chitosan membrane. Group $\mathrm{V}$ without therapy. Therapy was given once a day for 10 days. At the $5^{\text {th }}$ and $10^{\text {th }}$ half of animals/group were euthanized. Wound skin area were collected for hematoxylin-eosin and Mallory-azan stainings. Epithelial thickness and collagen density were observed and analyzed statistically. The results showed significant difference in epithelial thickness on the 5th and 10th days $(\mathrm{P} \leq 0.05)$ in combination group. Percentage of collagen density at 10th day of combination group showed significantly difference $(\mathrm{P} \leq 0.05)$ compared with control. The conclusion is combination of $1 \%$ chitosan membrane and eel mucous extract has the most potential to re-epithelization and increase density of collagen fibers in skin wound healing.
\end{abstract}

\section{Introduction}

Wound is an injury to anatomical structure which leads to tissue discontinuity. Wound, if left untreated, increases risk of infection which hinders it from an effective healing process. Staphylococcus aureus is a prominent etiology of skin infection that results in pus

\footnotetext{
*Corresponding author: estifkh@ugm.ac.id
} 
production[1].

The use of $10 \%$ iodine solution as antimicrobials has been debatable due to its toxic effect at cellular level [2]. On the other hand, the diversity of floral and faunal species in tropical countries provides us with many herbal options as alternatives. Parts of animals and plants are widely utilized as herbal medicine. Asian swamp eel (Monopterus albus) and snakehead Murrel (Channa striatus) are widely consumed by Southeast Asians and have been studied as treatment for kidney disease, erectile dysfunction, and to speed up surgical wound healing [3].

Asian swamp eel mucus, the primary protective agent to the fish, contains glycoprotein, lysozyme, immunoglobulin, and lectin which play important role as antimicrobials [4]. Chitosan, found in many crustacean shells, is biocompatible, biodegradable, has antioxidant and hemostatic properties. However, there are no studies to date that assess the medical benefit of Monopterus albus mucus and chitosan combined as wound dressing to improved healing process.

\section{Methods and Materials}

\subsection{Ethical Approval}

This study on animal subjects was approved by the Institutional Review Board of the Faculty of Veterinary Medicine, Universitas Gadjah Mada, Yogyakarta, Indonesia, with registration number : 0054/EC-FKH/Int./2019

\subsection{Tools and Materials}

Tools used in this study include animal cages, magnetic stirrer, weighing scale, centrifuge, biopsy punch ( $5 \mathrm{~mm}$ in diameter), a set of surgical instruments, light microscope. Materials used in this study were mice (Mus musculus), pellet and drinking water, rice hulls, eels (Monopterus albus), water, ketamine-xylazine as anesthesia, $10 \%$ povidone iodine solution, sterile gauze, adhesive bandage, cotton, sample pot, and 10\% PBS-buffered formaldehyde solution were used for skin biopsy, care, and sample collection. Hematoxylin-eosin, xylol, Mallory-Azan, paraffin, ethanol solution (with varying concentrations i.e., 70\%, 80\%, 90\%, and $100 \%$ ), mounting medium (Entellan $\left.{ }^{\circledR}\right)$, Dibuthylphtalate Polystyrene Xylene, object glass, cover glass, distilled water, physiologic saline solution, Hematoxylin-Eosin and Mallory-Azan histological dye.

\subsection{Animal Model Preparation and Treatment}

Thirty mice, 2-months old, male were acclimatized prior to skin wound and treatment. Skin wound were perform by punch biopsy in $0.5 \mathrm{~cm}$ diameter in a sterile manner. Skin wound was performed to all mice, and then mice were divided into 5 groups. The first group as the positive control group (mice in this group received $10 \%$ iodine solution covered by sterile gauze). Wounds of mice in group II were treated by eel mucus extract and sterile gauze. Mice in group III received a combination of chitosan membrane and eel mucus extract. Mice in group IV were given chitosan membrane only. Group $\mathrm{V}$ as the negative control group. Treatment was given once a day for 10 days. Observation was done twice, on the 5th and 10th days, where half of the mice within each group were euthanized at each period of observation before sample was obtained. 


\subsection{Mucus Extraction Procedure}

Eel mucus was obtained through swab technique. Eel was first rinsed using tap water twice, using distilled water afterwards. Swab was done on the dorsal surface of the eel to collect the mucus and then mucus was put in a conical tube. Tube was then centrifuged for 15 minutes at the speed of 5,000 rpm. Supernatant fraction was collected and kept at -4 centigrade [5].

\subsection{Chitosan Membrane Synthesis}

A modified chitosan membrane was made by diluting 1 gram of chitosan in $100 \mathrm{~mL}$ of $1 \%$ acetic acid solution. Solution was then homogenized using a magnetic stirrer for 15 minutes. The dope was poured to a flat surface on a clear PVC sheet. The dope was then left to dry on room temperature for 48 hours [6].

\subsection{Skin Wound Procedure}

Mice were anesthetized using ketamine at a dose of $40 \mathrm{mg} / \mathrm{kg}$ BW and xylazine at a dose of $5 \mathrm{mg} / \mathrm{kg} \mathrm{BW}$. The dorsum of the mice at the location of the biopsy was shaved. Skin wound was then performed using biopsy punch on the dorsum at the diameter of $5 \mathrm{~mm}$ with the depth reaching subcutaneous region $(0,2 \mathrm{~cm})$.

\subsection{Euthanasia and Organ Isolation}

Euthanasia and collection of specimens were performed on the 5th or 10th day after biopsy. Euthanasia was carried out by administering lethal dose of anesthesia intramuscularly. Skin excision was performed at the dimension of $1 \mathrm{~cm}$ by $1 \mathrm{~cm}$ using a sterile blade. Skin was then fixated in $10 \%$ PBS-buffered formaldehyde solution for 24 hours.

\subsection{Histopathology Slides Preparation}

Preparation began by trimming samples at the central part of the wound. Thus, we were able to observe the normal skin and the part in the healing phase. Samples were dehydrated with aethanol at multilevel concentration, i.e., 70\%, 80\%, 90\%, and absolute ethanol, for 60 minutes each. Clearing process using xylene solution and then paraffin infiltration of the sample was carried out in incubator at $60^{\circ} \mathrm{C}, 3$ times, 30 minutes each. Tissue embedding was done by immersing the tissue in liquid paraffin then leaving it at room temperature to form a paraffin block. The blocks were sliced with a $5 \mu \mathrm{m}$ then placed on the surface of warm water $\left(45^{\circ} \mathrm{C}\right)$ then mounted on the object glass.

\subsection{Hematoxylin-Eosin (HE) Staining}

Staining began with deparaffinization in xylol solution 3 times, then continued by rehydration in degradation concentration of ethanol from absolute to $70 \%$ for 5 minutes each and then rinsing them with distilled water. Slides were incubated in hematoxylin for 10 minutes and then rinsed in running tap water for 15 minutes. Slides were incubated in eosin solution for 5 mimutes and continued by dehydration process by soaking the slides for 3 minutes in $70 \%, 80 \%, 90 \%$ and absolute ethanol, 3 munites each. Clearing proses for the samples were conducted by incubated the slides in xylene, 3 times, 5 minutes each. Slides were then covered by cover glass using entelan as the mounting medium. This staining 
procedure conformed to the reference protocol at Laboratory of Microanatomy, Department of Anatomy, Faculty of Veterinary Medicine, Universitas Gadjah Mada.

\subsection{Mallory-Azan Staining}

Deparaffinization and rehydration was done in the same procedure as HE staining. Staining began by immersing the slides in Mallory I solution for 5 minutes then rinsed with distilled water three times. The staining process continued by immersing the slides in Mallory II solution for 6 minutes, followed by rinsing using distilled water five times. Lastly, the slides were once again soaked in Mallory III dye solution for 2 minutes and then rinsed with distilled water 5 times. Dehydration and cleaning process were then carried out before mounting the slides.

\subsection{Data Collection}

Observation was conducted microscopically on HE and Mallory-Azan-stained slides using Optilab® viewer at $12 \times 40$ magnification. Measurement of epithelial thickness was done using software (Image Raster (®) version 3.0) and HE-stained slides, in a position perpendicular to the basement membrane until the most superficial cell layer that was still attached to the epidermal layer. Measurements were made on three area, at both edges of wound and central part of the wound, and the mean value was calculated. Collagen density measurement was done at dermal area of the skin. Measurement of collagen area was done through software (Image $\mathbf{J}{ }^{\circledR}$ ) and displayed as percentage. Measurement was done in 5 fields of view, with one field at the center of wound healing, one at each edge of the wound and one at the middle third of the wound, then the average value was calculated.

\subsection{Statistical Analysis}

Data were statistically analyzed using SPSS version 16 (IBM, Inc.). Homogeneous, normally distributed data were analyzed using parametric independent $T$ test or two-way ANOVA test followed by post hoc analysis. Otherwise, data were analyzed using Kruskal-Wallis test and Mann-Whitney U test as the post hoc test to observe differences between groups. Statistical analysis was done at $95 \%$ confidence interval. P-value of 0.05 or less was regarded to be statistically significant.

\section{Result}

\subsection{Epithelial Thickness}

Epithelial thicknesses from each group are presented in Table 1.

Table 1. Epithelial thickness at the wound area, five and ten days after biopsy.

\begin{tabular}{lcc}
\hline \multirow{2}{*}{\multicolumn{1}{c}{ Group }} & \multicolumn{2}{c}{ Epithelial thickness (mean \pm SD) } \\
\cline { 2 - 3 } & \multicolumn{1}{c}{ Day 5 } & Day 10 \\
\hline Positive Control (I) & $89,49 \pm 2,23^{\mathrm{a}}$ & $77,83 \pm 3,16^{\mathrm{a}}$ \\
Mucus only (II) & $108,73 \pm 2,15^{\mathrm{a}, \mathrm{b}}$ & $45,47 \pm 5,98^{\mathrm{a}, \mathrm{d}}$ \\
Combination (III) & $142,89 \pm 2,24^{\mathrm{b}}$ & $42,43 \pm 0,55^{\mathrm{e}}$ \\
Chitosan Membrane only (IV) & $94,38 \pm 8,84^{\mathrm{a}}$ & $85,84 \pm 3,28^{\mathrm{a}}$
\end{tabular}


Negative Control (V)

$62,96 \pm 5,29^{\circ}$

$71,94 \pm 4,82^{\mathrm{c}}$

Quantitative analysis on epithelial thickness between groups on day 5 using KruskalWallis test showed statistically significant differences between groups $(\mathrm{p}=0,026)$. MannWhitney test was performed to assess with results displayed in the following table:

Table 2. Mann-Whitney test result on epithelial thickness 5 days after biopsy

\begin{tabular}{lccccc}
\hline & $\begin{array}{c}\text { Positive } \\
\text { Control }\end{array}$ & Mucus & Combination & $\begin{array}{l}\text { Chitosan } \\
\text { Membrane }\end{array}$ & $\begin{array}{l}\text { Negative } \\
\text { Control }\end{array}$ \\
\hline $\begin{array}{l}\text { Positive Control } \\
\text { Mucus }\end{array}$ & 0.275 & & & & \\
Combination & $0.050^{*}$ & 0.127 & & & \\
$\begin{array}{l}\text { Chitosan } \\
\text { Membrane }\end{array}$ & 0.827 & 0.275 & $0.050^{*}$ & & \\
Negative Control & $0.050^{*}$ & $0.050^{*}$ & $0.050^{*}$ & $0.050^{*}$ & \\
\hline
\end{tabular}

Note: shown above are p-values from Mann-Whitney test. * indicates statistically significant results.

The above results showed that positive control group has significantly different epithelial thickness compared to combination and negative control group ( $\mathrm{p} \leq 0.050)$, wherein combination group has higher mean of epithelial thickness on day 5 (Table 2). Epithelial thickness of the negative control group is significantly lower than any other group (Table 2). Statistically significant differences were also observed between combination and chitosan only group, in which chitosan only group has thinner epithelium compared to combination group.

Analysis of epithelial thickness on day 10 using ANOVA showed significant differences with p-value less than $0,05(<0,001)$. Results of post-hoc analysis are shown in table 3 .

Table 3. Mann-Whitney test result on epithelial thickness, 10 days after biopsy

\begin{tabular}{lcccll}
\hline & $\begin{array}{l}\text { Positive } \\
\text { Control }\end{array}$ & Mucus & Combination & $\begin{array}{l}\text { Chitosan } \\
\text { Membrane }\end{array}$ & $\begin{array}{l}\text { Negative } \\
\text { Control }\end{array}$ \\
\hline $\begin{array}{l}\text { Positive Control } \\
\text { Mucus }\end{array}$ & 0,068 & & & & \\
$\begin{array}{l}\text { Combination } \\
\begin{array}{l}\text { Chitosan } \\
\text { Membrane }\end{array}\end{array}$ & $0,047^{*}$ & 0,861 & & & \\
$\begin{array}{l}\text { Negative } \\
\text { Control }\end{array}$ & 0,644 & $0,024^{*}$ & $0,016^{*}$ & & \\
\hline
\end{tabular}

Note: $*$ indicates statistically significant results.

Post-hoc analysis showed a statistically significant difference between positive control group and combination group, in which combination group has thinner epithelium than positive control group on $10^{\text {th }}$ day (Table 3). Statistically significant difference was also observed between mucus group and chitosan group where chitosan group has lower epithelial thickness compared to mucus group. Mice that were treated with the combination of mucus extract and chitosan membrane had significantly thinner epithelium than mice in the chitosan membrane only group and negative control group. This study showed that mice in combination group have the lowest mean value of epithelial thickness on day 10, compared to other groups. 
Regarding time to wound recovery, Kruskal-Wallis test revealed significant differences in terms of epithelial thickness on day 5 and day 10 post-biopsy in all groups $(p=0.006)$, which showed us association of time and epithelial thickness. Mann-Whitney test performed to assess differences of epithelial thickness on day 5 and day 10 between mucus group and combination group also showed significant results $(p \leq 0.05)$ (Table 1). Mucus group and combination group had greater decrease in epithelial thickness compared to positive control group, chitosan membrane group, and negative control group. Mucus group and combination group had lower mean of epithelial thickness compared to the other group on day 10

Observation of histopathological skin wound on day 5 using HE staining at low power magnification (Figure 1) revealed complete coverage of granulation tissue by newly formed epithelium in mucus group, chitosan group and combination group, while partial coverage was observed in positive and negative control groups. Accumulation of crusts was observed microscopically in the mucus group and negative control group.

Observation of the healthy part of skin (adjacent to the wound area) at 48x magnification reveals thin epithelial tissue forming the epidermal layer, hair follicle, and subcutaneous layer of the skin (Figure 2).

Observation of healthy mice skin at higher magnification (Figure 3) showed a thin epidermal layer, at approximately $25,27 \mu \mathrm{m}$ thick. Stratum lucidum was not observed. On day 5 , it was observed that the spinous layer dominated the epidermal layer in mucus group and combination group (Figure 4). The cells comprising spinous layer were also found in the chitosan membrane group, positive and negative control groups, although not as abundant as those found in mucus and combination groups.
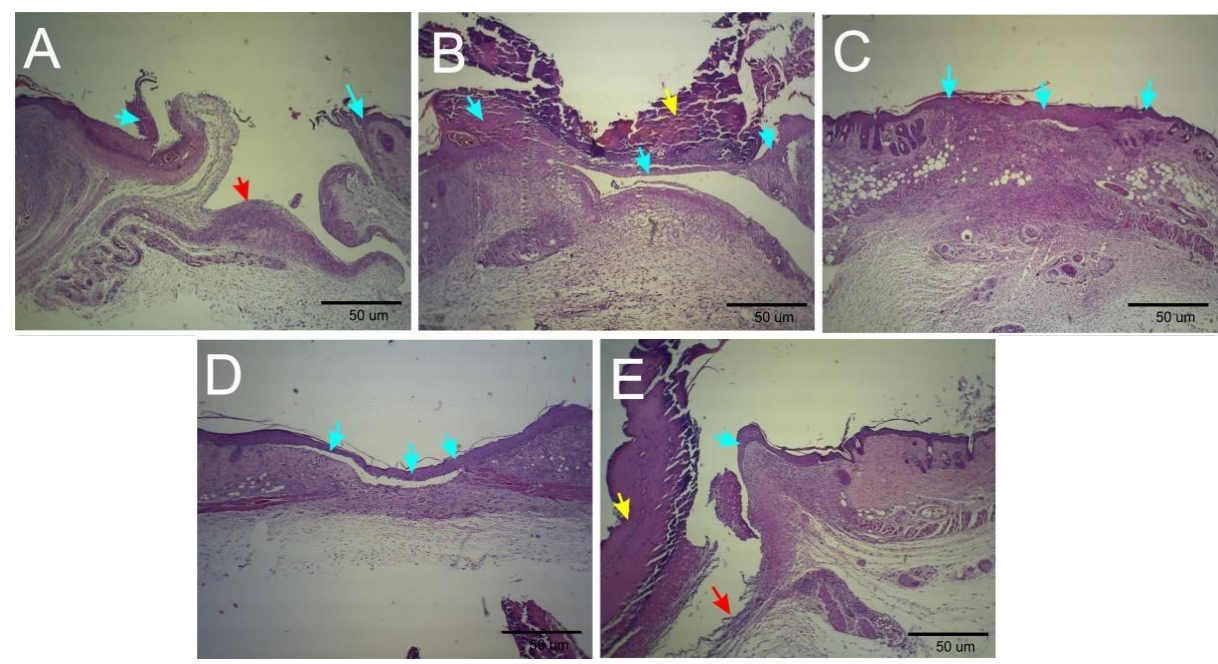

Fig. 1. Re-epithelialization of mice skin on the $5^{\text {th }}$ day. Hematoxylin-Eosin, low magnification. Note: blue arrow points at newly formed epithelium. Red arrow indicates granulation tissue not covered by epithelium. Yellow arrow indicates crusts. (A) positive control group, (B) mucus group, (C) combination group, (D) chitosan group, (E) negative control group. 


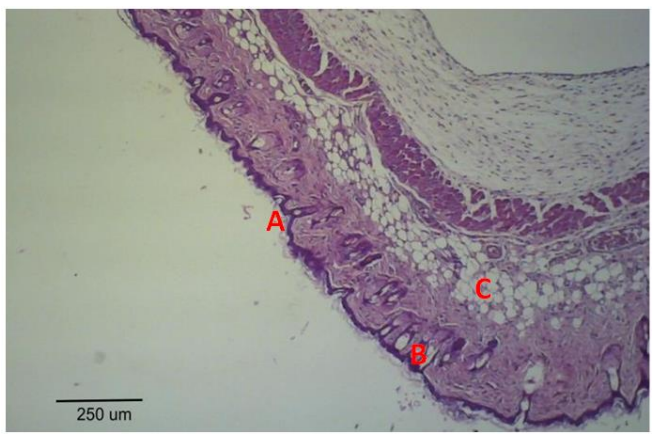

Fig. 2. Histology of healthy skin on the back of mice with a weak magnification scale of 250 $\mu \mathrm{m}$. A. Thin epithelial tissue comprising the epidermis. B. Hair follicles in the dermis, leading to the epidermis. C. Subcutis with predominant fatty tissue.

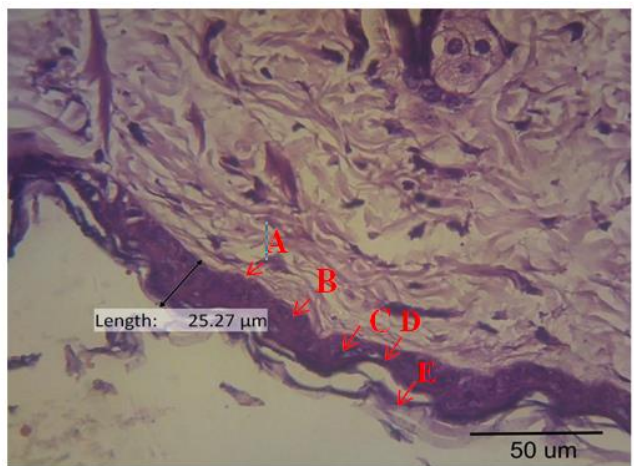

Fig. 3. Histology of epithelial tissue forming the epidermal layer of healthy skin adjacent to wound. Hematoxylin-Eosin, high magnification. Note: (A) basal membrane, (B) basal layer of epidermis. (C) spinous layer, (D) granular layer, and (E) corneal layer
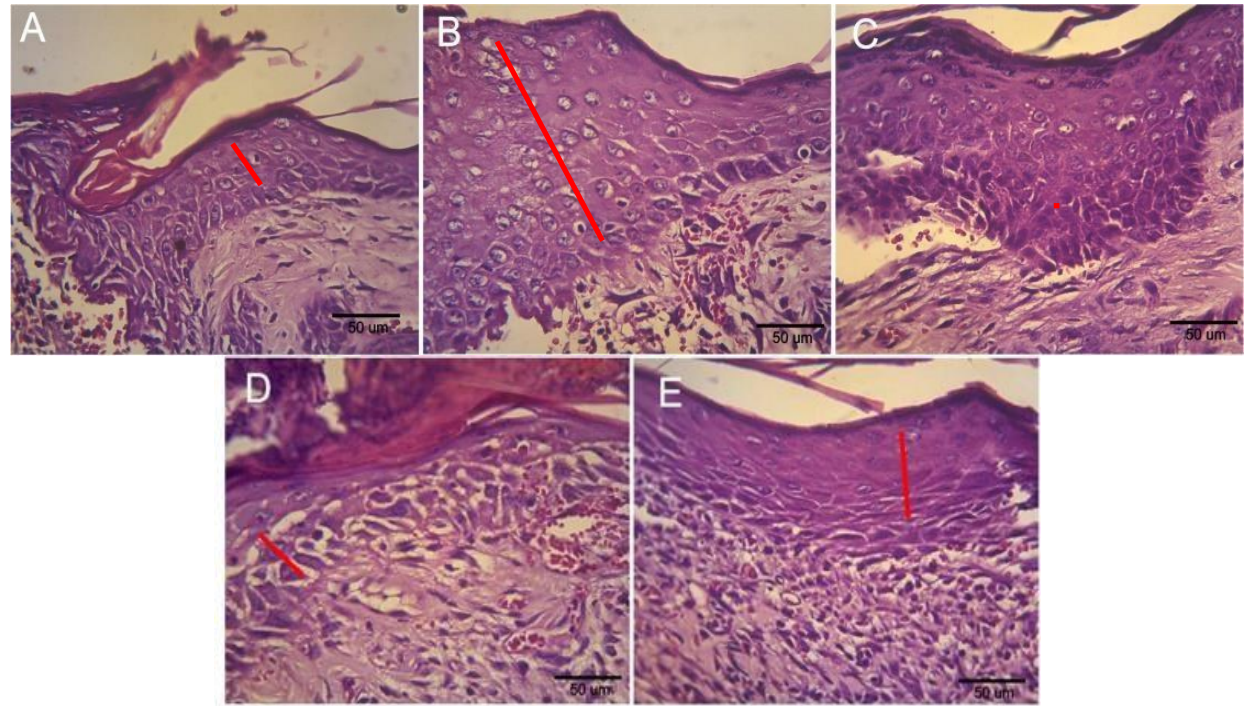

Fig. 4. Re-epithelialization of mice skin on day 5. Hematoxylin-Eosin, high magnification. Note: (A) positive control group, (B) mucus group, (C) combination group, (D) chitosan group, (E) negative control group. Red lines mark spinous layers. 
Mean of epithelial thickness on the $10^{\text {th }}$ day decreased from what was observed on the $5^{\text {th }}$ day in all groups (Table 1). However, cells comprising epidermal layers looked more compacted, resembling more those in normal skin. Hair follicle started forming in the combination group. This finding was not observed in other groups (Figure 5).

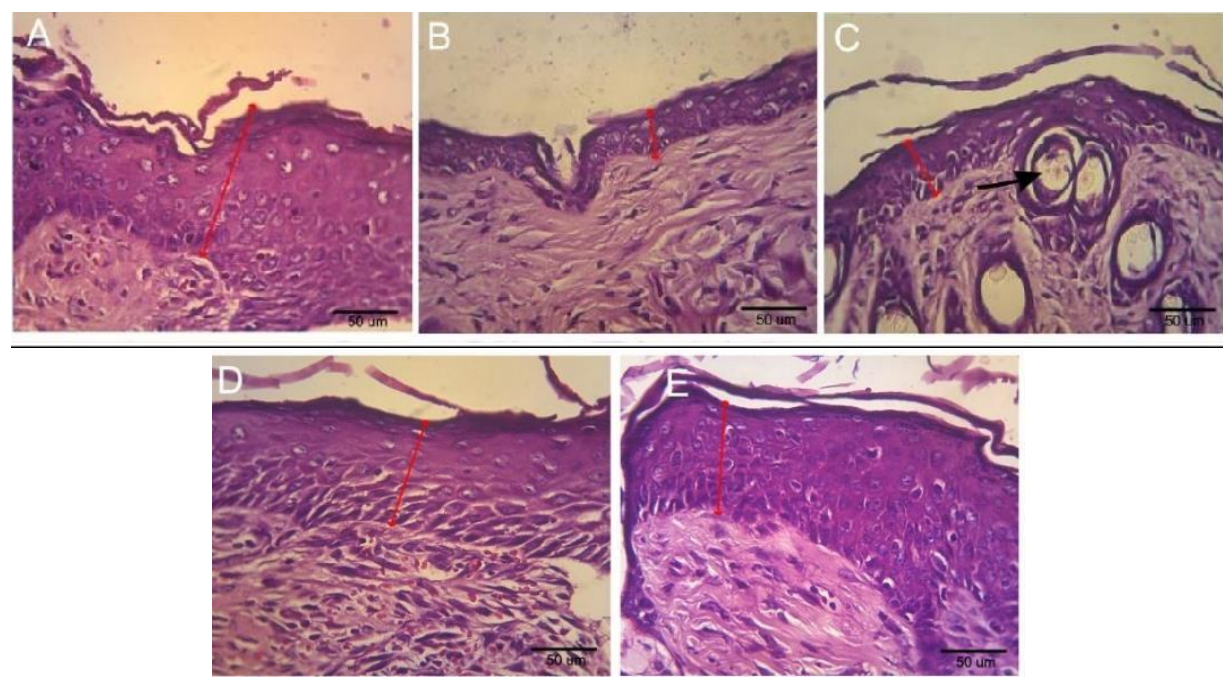

Fig. 5. Re-epithelialization of mice skin on day 10. Hematoxylin-Eosin, high magnification. Note: (A) positive control group, (B) mucus group, (C) combination group, (D) chitosan group, (E) negative control group. Red lines mark spinous layers.

\subsection{Collagen Fiber Density}

Results of collagen density measurement are shown in table 4.

Table 4. Collagen fiber densities in wound area, 5 and 10 days after biopsy

\begin{tabular}{cccc}
\hline Group & \multicolumn{2}{c}{ Percentage, mean \pm SD } & \multirow{2}{*}{$p$-value } \\
\cline { 2 - 3 } & Day 5 & Day 10 & \\
\hline Positive Control & $23.02 \pm$ & $21.23 \pm$ & 0.579 \\
Mucus & 5.09 & $0.72^{\mathrm{a}}$ & \\
& $16.08 \pm$ & $22.90 \pm$ & 0.306 \\
Combination & 8.84 & $4.87^{\mathrm{a}}$ & \multirow{2}{*}{$0.017^{*}$} \\
Chitosan & $22.93 \pm$ & $37.04 \pm$ & \\
& 4.24 & $4.60^{\mathrm{b}}$ & \multirow{2}{*}{0.371} \\
Negative Control & $15.07 \pm$ & $19.31 \pm$ & \\
& 5.14 & $5.16^{\mathrm{a}}$ & \multirow{2}{*}{0.695} \\
P value & $12.49 \pm$ & $14.55 \pm$ & \\
\hline
\end{tabular}

Note: * indicates significant differences in terms of collagen fiber density between day 5 and day 10. Superscripts flag significant differences between groups. P-values were obtained by post-hoc analysis.

Results from two-way ANOVA showed significant difference of collagen fiber density between groups within same day of observation. Percentages of collagen density between 
day 5 and day 10 were also statistically different with P-value of 0.018 . Effect of treatment groups and day of observation on collagen density did not produce significant result $(\mathrm{p}=$ 0.164).

Results from between subject-effect test on collagen density on day 10 showed significant differences among groups $(\mathrm{P}=0.004)$. Post-hoc analysis is presented on table 5 below.

Table 5. Post-Hoc analysis on collagen fiber densities (as percentage of area) on day 10

\begin{tabular}{lccccc}
\hline & $\begin{array}{c}\text { Positive } \\
\text { Control }\end{array}$ & $\begin{array}{c}\text { Mucu } \\
\mathrm{s}\end{array}$ & $\begin{array}{c}\text { Combinatio } \\
\mathrm{n}\end{array}$ & $\begin{array}{c}\text { Chitosan } \\
\text { Membran } \\
\mathrm{e}\end{array}$ & $\begin{array}{c}\text { Negativ } \\
\mathrm{e} \\
\text { Control }\end{array}$ \\
\hline $\begin{array}{l}\text { Positive } \\
\text { Control }\end{array}$ & & & & & \\
$\begin{array}{l}\text { Mucus } \\
\text { Combination }\end{array}$ & $\begin{array}{c}0.705 \\
0.004\end{array}$ & $\begin{array}{c}0.008 \\
*\end{array}$ & & & \\
$\begin{array}{l}\text { Chitosan } \\
\text { Membrane }\end{array}$ & 0.666 & 0.424 & $0.002^{*}$ & & \\
$\begin{array}{l}\text { Negative } \\
\text { Control }\end{array}$ & 0.153 & 0.081 & $0.000^{*}$ & $0.295^{*}$ & \\
\hline
\end{tabular}

Note: * flags statistically significant difference between groups

Results of post-hoc analysis showed significant difference of collagen fiber density between combination group and positive control group on day 10, wherein positive control group had lower percentage of collagen fiber density than the combination group. Collagen fibers in the mucus group were also significantly less dense than in the combination group. Collagen fiber in the combination group on day 10 was more packed than in the chitosan membrane group and negative control group (Table 4). Negative control group had the lowest percentage of collagen fiber density among other groups. Thereby, the combination group had the most packed collagen fiber, followed by mucus group, positive control group, chitosan membrane group, and negative control group.

Difference in percentage of collagen density between day 5 and day 10 of intervention was further analyzed using an independent $T$ test. This study found statistically significant differences in collagen density between day 5 and day 10 within the combination group (pvalue of 0.017 ). Increase in the percentage of collagen fiber density was highest in the combination group compared to other groups (Table 4).

Qualitative analysis of collagen fiber on day 10 (Figure 6) revealed growth of bluecolored collagen in all treatment groups. Collagen fiber in combination group (C) were darker in color than other groups, which resembled the color of collagen fiber found in healthy tissue sample $(\mathrm{F})$. 

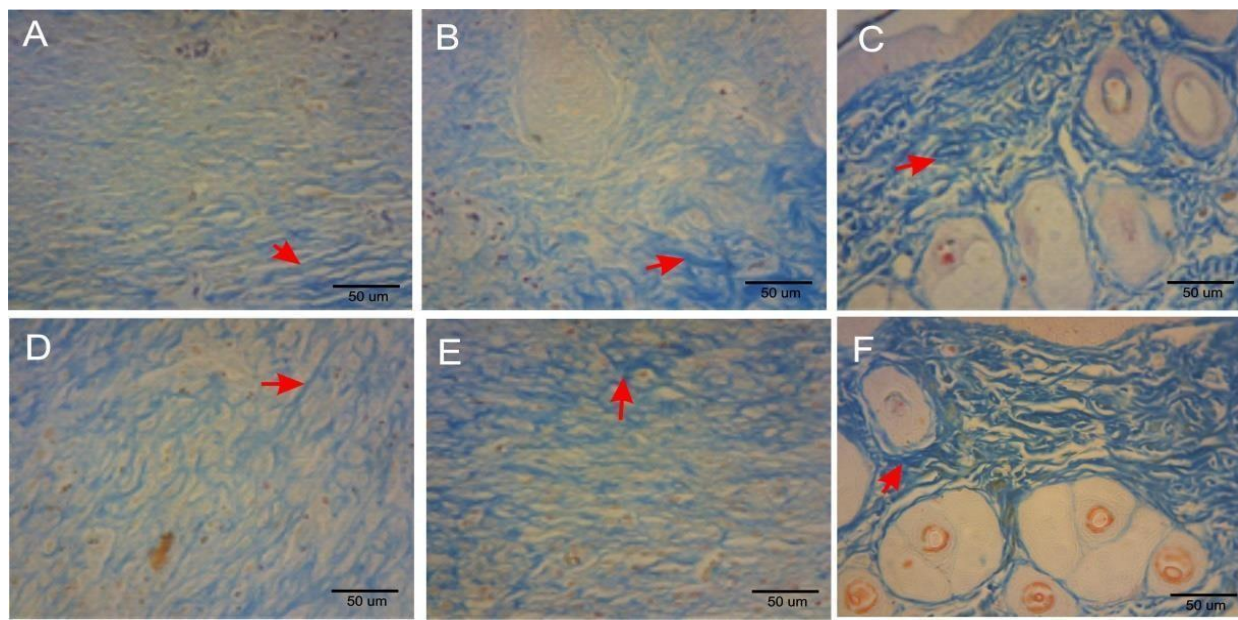

Fig. 6. Collagen fiber in the dermal layer in all groups, 10 days after biopsy. Mallory-Azan staining, high magnification. Note: (A) positive control group, (B) mucus group, (C) combination group, (D) chitosan membrane group, (E) negative control group, (F) normal skin. Arrow shows collagen fiber, which was blue-stained.

\section{Discussion}

\subsection{Epithelial Thickness}

We revealed that better epithelial tissue growth in groups of positive control, mucus group, chitosan, and combination than in negative control group. Progressive healing process occurred in the combination group, where thickest epithelium was found on day 5 post biopsy.

The cutaneous epithelial growth pattern in this study was similar to what was found by [7] where epithelial tissue reached its peak thickness on the $7^{\text {th }}$ day and decreased further until the $21^{\text {st }}$ day on mice treated with $10 \%$ povidone-iodine solution, saliva and physiologic saline. The decrease in epithelial thickness after 10 days of treatment occurred due to the epithelial tissue that had covered the wound surface completely and no proliferation. Epithelial tissue that has covered the whole wound area stops proliferating and starts the maturation process, characterized by keratin synthesis by corneal layer of epithelium. Study conducted by Putri and Tasminatun in 2016 [8]also reported peak epithelial thickness on day 7 followed by decrease on the next day. [9] found that epithelial thickening would continue and then regress until it reaches normal thickness. This study found that 10 days after biopsy, mice receiving combination of mucus extract and chitosan membrane had the thinnest epithelium.

Crusts, found at the margin of the wound in this study, are made from dried exudates and are observable as solid layer on the outside [10]. Debris and exotoxin found in exudates may slow down the wound healing process and pose a risk of advanced infection [11].

The skin layer observed in this study was in accordance with [12], which stated that epidermis has varying layers forming it across sites. [13] stated that cells forming spinous and basal layers have clear mitotic figures to replace the cells lying on top of them. This observation was also in keeping with data from epithelial thickness measurement wherein thick epithelia were observed in the combination group and mucus group due to spinous cells predominance in the epithelial tissues in both groups. Predominance of spinous cells marked the proliferation process in tandem with the wound healing process. Granular layer was not 
observed on day 5. This may partially be due to the keratinocyte deposition process which had not occurred yet.

Epidermis is the outermost skin layer and becomes a physical barrier of the tissue beneath it [14]. According to [1], tissue discontinuity due to trauma triggers physiologic response to recover the structural and functional loss.

[15] stated that in the wound healing process, keratinocytes actively proliferate due to stimulation by epidermal growth factor (EGF), keratinocyte growth factor (KGF), and transforming growth factor- $\alpha$ (TGF- $\alpha)$. [16] reported that in traumatic wounds in the buccal area, human keratinocytes migrate laterally and synthesize basal membrane then halt the migration process and proliferate actively until the $4^{\text {th }}$ day. Keratinocyte migration has been shown by [17] through immunofluorescent staining using CK17, which detects keratinocyte migration from the border of wound to granulation tissue to synthesize basal membrane. Progressive increase in epithelial thickness in combination group 5 days post biopsy may partially be due to hemostatic effect of chitosan, therefore able to stop bleeding more swiftly and provide extracellular matrix for epithelial cells to attach during wound healing process. Chitosan structure resembles glycosaminoglycan, a polysaccharide found in extracellular tissue. Lactoferrin, a peptide found in eel mucus, may increase production of proinflammatory cytokines by macrophages. Inflammatory cytokines may modulate keratinocyte migrations to wound area, thereby speed up the healing process. Qualitative observation also showed complete coverage of wound area by epithelial tissue in all mice receiving combination of mucus extract and chitosan membrane and few mice treated with mucus only or chitosan membrane only.

Study by [18] to evaluate the performance of chitosan membrane as wound dressing found that better wound healing process occurred in tissues that had thinnest epithelial tissue, which marked completed growth stimulation by growth factor and other mediators. [7] found that epithelial reconstruction was better in animal treated with saliva than with $10 \%$ povidoneiodine solution. Histopathological observation also indicated better epithelial repair in the combination group supported by the development of hair follicle which was not found in other groups (Figure 5). Combination of chitosan membrane and eel mucus extract speeds up reepithelialization better than $10 \%$ povidone-iodine solution.

\subsection{Collagen Fiber Density}

According to [19] regeneration of wound skin start from matrix formation which encloses the wound. During proliferation stage, wound form scar tissue in the deep area as the result of fibroblast activity . [20] stated that synthesize collagen by fibroblast to form new tissue is stimulate by macrophages that migrating to wound area and secreting transforming growth factor- $\beta$ (TGF- $\beta$ ). For that reason, this study observed the effect of intervention on collagen fiber density at wound site.

Transforming growth factor- $\beta$ may played a role in the proliferation phase in this study but it needs to be confirmed in further studies by using more specific staining method. According to [21], once inflammation phase is finished, macrophages will turn into the M2type (anti-inflammatory macrophages) which express anti-inflammatory mediators, namely, protease, protease inhibitor, vascular endothelial growth factor (VEGF) and TGF- $\beta$ which promote protein synthesis and cellular proliferation. Fibroblast migration and proliferation trigger collagen fiber and fibronectin syntheses which, in turn, increase extracellular matrix. Collagen fiber synthesis is paramount to strengthen the tissue after injury [19] and [22]. Collagen is secreted to extracellular space in the form of procollagen which forms tropocollagen. Tropocollagen then unites to form collagen fibers. Collagen synthesis begins as early as three days after trauma and occurs rapidly then reaches its peak 14 days after trauma, which is characterized by collagen fiber thickening [23]. 
Administration of $10 \%$ povidone-iodine solution to wounded tissue may slow down the proliferation of fibroblast, which in turn decreases the speed of collagen synthesis. This study showed a decrease in collagen density (displayed as percentage) from day 5 to day 10 , although this decrease was not statistically significant (Table 4). [18] stated that in terms of wound care, administration of povidone-iodine solution must be minimized due to its cytotoxic effect on fibroblasts. This study is also in concordance with study by Danastri et al. in 2014 which assessed the effect of povidone-iodine solution at concentration higher than $0.1 \%$ on fibroblasts and polymorphonuclear cells based on fast protein liquid chromatography (FPLC) method.

The progressive increase of collagen density which was observed in the combination group supports the previous finding by [24], which stated that chitosan is able to prolong the halflife of basic fibroblast growth factor (FGF) by protecting it from enzymatic degradation. Therefore, fibroblasts may function more optimally. On the other hand, Immunoglobulin M, which is found in mucus of Asian swamp eel, plays an important role to protect the host from proteolytic degradation [25]. The benefits from these two on wound healing may reflect potencies for use as treatment for wound, alternative to gauze and $10 \%$ povidone-iodine solution, to speed up the wound healing process.

\section{Conclusion}

This study concluded that application of chitosan membrane (1\% b/v), combined with $100 \%$ Asian swamp eel (Monopterus albus) mucus sped up the re-epithelialization process and increased the collagen fiber density in mice (Mus musculus) undergoing skin wound. Findings from this study may be the basis for further research to compare their efficacy as alternatives to conventional wound dressings.

\section{References}

1. V. Kumar, A. Abbas, J. Aster, S. Robbins, J. Perkins, Robbins, Basic Pathology (Elsevier Saunders, Philadelphia, 2013)

2. A. Muhammad, Konsep Dasar Sistem Pakar (Penerbit Andi, Yogyakarta, 2005)

3. A.B. Atif, M.K. Zahri, A.R. Esa, B.A. Zilfalil, U.S.M. Rao, S. Nordin, J. Appl. Pharmaceutical Sc. 5, 1 (2015)

4. N.M. Hussin, S.M. Shaarani, M.R. Sulaiman, A.H., Ahmad, C.S.Vairappan, Chemical Composition and Antioxidant Activities of Catfish Epidermal Mucus, J. Adv. AgricTech. 4, 1 (2017)

5. M. N. N. M Ikram and B. H. Ridzwan, Inter Res J Pharma and Pharmacol 3, 1 (2013)

6. D.A. Setiawan, B.D. Argo and Y. Hendrawan, Jurnal Keteknikan Pertanian Tropis dan Biosistem 3, 1 (2015)

7. I.A. Wahyudi, M. Magista and M.Angel, Efektivitas Penggunaan Saliva dibandingkan Povidone Iodine 10\% terhadap Penyembuhan Luka pada Kutaneus Tikus Sprague dawley, IDJ 2, 1 (2013)

8. F.R. Putri and S. Tasminatun, J. Kedokteran dan Kesehatan 12, 1 (2016)

9. W.K. Fathi, Al - Rafidain Dent J. 12, 1 (2012)

10. W.W. Dorland, Kamus Kedokteran Dorland (EGC, Jakarta, 2002)

11. M.J. Morison, Manajemen Luka, (EGC, Jakarta, 2004)

12. W.J. Banks, Applied Veterinary Histology (Lippincott Williams and Wilkins, New York, 1993) 
13. S.J. Kalangi, Histofisiologi Kulit, JBM 5, 3 (2013)

14. S. Baranoski and R.N. Ayello, Wound Care Essentia : Practice Principle 3rd Edition (Lippincott Williams and Wilkins. New York,2012)

15. A.J. Singer and R.A.F. Clark, Cutaneous Wound Healing, NEJM 341, 10 (1999)

16. O.J. Andreasen, F.M. Andreasen and L. Andreasen, Textbook and color atlas of traumatic injuries to the teeth (Wiley Blackwell, Oxford, 2013)

17. I. Pastar, O. Stojadinovic, N.C. Yin, H. Ramirez, A.G. Nusbaum, A. Sawaya, S.B. Pate, L. Khalid, R.R. Isseroff, and M.T. Canic, Adv. Wound Care 3, 7 (2014)

18. A.D. Sezer, F. Hatipolu, E. Cevher, Z. Ourtan, A.L. Ba, J.Akbua, AAPS Pharm. Sci. Tech. 8, 1 (2007)

19. M.M. Pavletic, Atlas of Small Animal Wound Management and Reconstructive Surgery $3^{\text {rd }}$ Edition (Willey Blackwell, Iowa, 2010)

20. I.M.S. Wijaya, Perawatan Luka dengan Pendekatan Multidisiplin (ANDI publisher, Yogyakarta, 2018)

21. A.R. Pratama, N. Wathoni, and T. Rusdiana, Jurnal Farmaka 15, 2 (2017)

22. T. Velnar, T. Bayley, and V.Smrkolj, The Wound Healing Proses: an Overview of The Cellular and Molecular Mechanisms. J Inter Med Res. 37 (2009)

23. A.I.M. Novitasari, R Indraswary, R. Pratiwi, ODONT Dent. J. 4, 1 (2017)

24. K. Masuoka, M. Ishahara, T. Asazuma, H. Hattori, T. Matsui, B. Takase, J.biomaterial 26, 19 (2005)

25. M.A. Esteban, An overview of the Immunological Defense in Fish Skin, ISRN Immunol 29 (2012) 